\title{
Correlations between lymph concentrations of cytokine and cell morphometric parameters of mesenteric lymph nodes in rats with chemically induced breast cancer
}

\author{
Oleg Kazakov \\ Research Institute of Clinical and \\ Experimental Lymphology - Branch of \\ the Institute of Cytology and Genetics \\ Siberian Branch of the Russian \\ Academy of Sciences \\ Novosibirsk, Russia \\ kazakoff_oleg@mail.ru \\ Alexey Kabakov \\ Research Institute of Clinical and \\ Experimental Lymphology - Branch of \\ the Institute of Cytology and Genetics \\ Siberian Branch of the Russian \\ Academy of Sciences \\ Novosibirsk, Russia \\ kabakov_av85@mail.ru \\ Vladimir Konenkov \\ Research Institute of Clinical and \\ Experimental Lymphology - Branch of \\ the Institute of Cytology and Genetics \\ Siberian Branch of the Russian \\ Academy of Sciences \\ Novosibirsk, Russia \\ vikonenkov@gmail.com
}

\author{
Alexandr Poveshchenko \\ Research Institute of Clinical and \\ Experimental Lymphology - Branch of \\ the Institute of Cytology and Genetics \\ Siberian Branch of the Russian \\ Academy of Sciences \\ Novosibirsk, Russia \\ poveshchenkoa200@mail.ru.
}

Alexandr Lykov

Research Institute of Clinical and

Experimental Lymphology - Branch of

the Institute of Cytology and Genetics

Siberian Branch of the Russian

Academy of Sciences

Novosibirsk, Russia

aplykov2@mail.ru

\author{
Nikolai Orlov \\ Research Institute of Clinical and \\ Experimental Lymphology - Branch of \\ the Institute of Cytology and Genetics \\ Siberian Branch of the Russian \\ Academy of Sciences \\ Novosibirsk, Russia \\ nbo@ngs.ru \\ Dmitry Strunkin \\ Research Institute of Clinical and \\ Experimental Lymphology - Branch of \\ the Institute of Cytology and Genetics \\ Siberian Branch of the Russian \\ Academy of Sciences \\ Novosibirsk, Russia \\ Strunkind@mail.ru
}

\begin{abstract}
The correlation analysis between morphometric parameters and number of immunocytes of mesenteric lymph nodes with the thoracic duct lymph cytokines levels on chemically induced rat model of breast cancer (BC) was done. It is shown that in $\mathrm{BC}$ group the activity of the local immune response in the lymph nodes is aimed at antitumor protection. In BC group the area of the paracortical zone was similar as on intact group, the area of lymphoid nodules with germinative centers and the area of medullary substance are increased, the number of macrophages in the thymus-dependent zone and zone responsible for humoral immunity are increased. In BC group was observed positive correlation between: dividing cells in germinative and medullar substance and IL-5; between number of the medium size of lymphocytes and MIP-1 $\alpha$; between the number of immunoblasts in germinative centers and $\mathrm{GRO} / \mathrm{KC}$; between the number of macrophages and MCP-1; between the number of reticular cells and IL-6, and M-CSF; between the number of small size lymphocytes and the number of mature plasma $B$ cells and $\mathbf{G r o} / \mathrm{KC}$, that can be caused by their migration from lymph nodes.
\end{abstract}

Keywords - breast cancer, Wistar rat, mesenteric lymph node, cytokines, morphometry

\section{Introduction}

One of the pathogenetic mechanisms of tumor development and progression is protein mediators - cytokines, chemokines and growth factors. It has been shown that cytokines secreted by both lymphoid and tumor cells affect various target cells and play an important role in the pathogenesis of tumor growth and metastasis, which proceeds mainly lymphogenously [1]. The aim of the study was to assess the correlation between thoracic lymphocytokines and morphological parameters of the structural and functional zones of the mesenteric lymph nodes in a model of rat breast cancer.

\section{Materials and Methods}

The study was done on 40 female Wistar. Animal was divided into: control (intact) group and $\mathrm{BC}$ group. $\mathrm{BC}$ was induced by injection of N-methyl-N-nitrosourea (MNU) 5 times with an interval of 7 days, subcutaneously in the region of the $2^{\text {nd }}$ breast on the right side. Rats were removed from the experiment 6.5 months after induction of $\mathrm{BC}$ under anesthesia. Lymph was taken from the cistern of the thoracic lymphatic duct. Concentrations of 24 cytokines in lymph were assessed by flow fluorimetry using Bio-Plex Pro Rat Cytokines 24-Plex Assay (Bio-Rad, USA). Spearman r rank was done to estimate correlation.

\section{Results}

Table 1 summarized the estimated correlations between the concentrations of lymph cytokines and the morphological parameters of the mesenteric lymph node. It was found that the increased area of the germinal centers of lymphoid nodules and medullary substance positively correlates with the number of mitotic cells in germinal centers (the number of which is increasing) and medullary substance with IL-5. IL-5 produced by Th2 and stimulates proliferation and differentiation of 
activated B-cells. Correlation of middle size lymphocytes of germinative centers and medullary cords with chemokine MIP- $1 \alpha$ and correlation of the number of immunoblasts with $\mathrm{GRO} / \mathrm{KC}$ cytokine, which determines the chemotaxis of immunocompetent cells, may also indicate the preservation of the activity of local immune response. Structural changes

TABLE I. THE PARAMETERS OF SPIRMEAN R-RANK ESTIMATED BETWEEN THORACIC LYMPH CYTOKINES LEVELS AND MORPHOLOGICAL AND CELLULAE PERAMETERS OF MESENTERIAL LYMPH NODE ON RAT BREAST CANCER MODEL

\begin{tabular}{|c|c|c|c|c|c|c|c|c|c|c|c|}
\hline 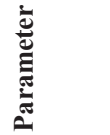 & 을 & $\stackrel{+}{=}$ & $\stackrel{1}{1}$ & $\stackrel{\stackrel{i}{=}}{=}$ & $\frac{3}{3}$ & 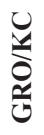 & 壳 & $\sum_{\substack{1 \\
2}}^{\frac{1}{2}}$ & $\stackrel{\frac{\pi}{1}}{\stackrel{1}{\xi}}$ & 竞 & $\tilde{U}^{\prime \prime}$ \\
\hline \multicolumn{12}{|c|}{ Germinative centers of secondary lymphoid nodules } \\
\hline \multirow{2}{*}{$\begin{array}{l}\text { Immun } \\
\text { oblasts }\end{array}$} & $\begin{array}{l}\mathrm{B} \\
\mathrm{C}\end{array}$ & - & - & - & - & $\begin{array}{l}0 . \\
9\end{array}$ & - & - & - & - & - \\
\hline & $\begin{array}{l}\mathrm{B} \\
\mathrm{C}\end{array}$ & - & - & - & - & $\begin{array}{l}0 . \\
95 \\
\end{array}$ & - & - & - & - & - \\
\hline \multirow{2}{*}{$\begin{array}{c}\text { Mediu } \\
\text { m size } \\
\text { lympho } \\
\text { cytes }\end{array}$} & $\begin{array}{l}\mathrm{I} \\
\mathrm{n}\end{array}$ & - & - & - & - & - & $\begin{array}{l}0 . \\
9\end{array}$ & - & - & - & $\begin{array}{l}0 . \\
9\end{array}$ \\
\hline & $\begin{array}{l}\mathrm{B} \\
\mathrm{C}\end{array}$ & - & - & - & - & - & - & - & $\begin{array}{l}0 . \\
9\end{array}$ & - & - \\
\hline $\begin{array}{l}\text { Reticula } \\
\text { r cells }\end{array}$ & $\begin{array}{l}\mathrm{B} \\
\mathrm{C}\end{array}$ & - & - & - & $\begin{array}{l}0 . \\
95\end{array}$ & - & - & - & - & - & - \\
\hline \multirow{2}{*}{ Mitosis } & $\begin{array}{l}\mathrm{I} \\
\mathrm{n}\end{array}$ & - & - & - & - & - & $\begin{array}{l}0 . \\
95\end{array}$ & - & - & - & - \\
\hline & $\begin{array}{l}\mathrm{B} \\
\mathrm{C}\end{array}$ & - & $\begin{array}{l}0 . \\
98\end{array}$ & - & - & - & - & - & - & - & - \\
\hline \multicolumn{12}{|c|}{ Paracortical zone } \\
\hline \multirow{2}{*}{$\begin{array}{c}\text { Macrop } \\
\text { hage }\end{array}$} & $\begin{array}{l}\mathrm{I} \\
\mathrm{n}\end{array}$ & - & $\begin{array}{l}0 . \\
97 \\
\end{array}$ & - & - & - & - & - & - & - & $\begin{array}{l}0 . \\
97\end{array}$ \\
\hline & $\begin{array}{l}\mathrm{B} \\
\mathrm{C}\end{array}$ & - & - & - & - & - & - & - & - & - & $\begin{array}{l}0 . \\
95\end{array}$ \\
\hline $\begin{array}{l}\text { Reticula } \\
\text { r cells }\end{array}$ & $\begin{array}{l}\mathrm{B} \\
\mathrm{C}\end{array}$ & - & - & $\begin{array}{l}0 \\
\dot{9}\end{array}$ & - & - & - & $\begin{array}{l}0 . \\
9\end{array}$ & - & - & - \\
\hline $\begin{array}{l}\text { Mast } \\
\text { cells }\end{array}$ & $\begin{array}{l}\mathrm{B} \\
\mathrm{C}\end{array}$ & - & $\begin{array}{l}0 . \\
95\end{array}$ & - & - & - & - & - & - & - & - \\
\hline \multicolumn{12}{|c|}{ Medullary substance } \\
\hline $\begin{array}{c}\text { Mediu } \\
\text { m size } \\
\text { lympho } \\
\text { cytes }\end{array}$ & $\begin{array}{l}\mathrm{B} \\
\mathrm{C}\end{array}$ & - & - & - & - & - & - & - & $\begin{array}{l}0 . \\
9\end{array}$ & - & - \\
\hline $\begin{array}{l}\text { Small } \\
\text { size } \\
\text { lympho } \\
\text { cyte }\end{array}$ & $\begin{array}{l}\mathrm{I} \\
\mathrm{n}\end{array}$ & $\begin{array}{l}0 . \\
95\end{array}$ & - & - & - & - & - & - & - & $\begin{array}{c}0 . \\
97\end{array}$ & - \\
\hline $\begin{array}{c}\text { Immun } \\
\text { oblasts }\end{array}$ & $\begin{array}{l}\mathrm{I} \\
\mathrm{n}\end{array}$ & $\begin{array}{c}0 . \\
89\end{array}$ & - & - & - & - & - & - & - & - & - \\
\hline $\begin{array}{c}\text { Macrop } \\
\text { hage }\end{array}$ & $\begin{array}{l}\mathrm{I} \\
\mathrm{n}\end{array}$ & - & - & - & - & - & - & $\begin{array}{l}0 . \\
95\end{array}$ & - & - & - \\
\hline Mitosis & $\begin{array}{l}\mathrm{B} \\
\mathrm{C}\end{array}$ & - & $\begin{array}{l}0 . \\
9\end{array}$ & - & - & - & - & - & - & - & - \\
\hline \multicolumn{12}{|c|}{ Medullary sinuses } \\
\hline \multirow{2}{*}{$\begin{array}{l}\text { Small } \\
\text { lympho } \\
\text { cyte }\end{array}$} & $\begin{array}{l}\mathrm{I} \\
\mathrm{n}\end{array}$ & - & - & - & $\begin{array}{l}0 . \\
9 \\
\end{array}$ & - & - & - & - & - & - \\
\hline & $\begin{array}{l}\mathrm{B} \\
\mathrm{C}\end{array}$ & - & - & - & - & $\begin{array}{l}0 . \\
9\end{array}$ & - & - & - & - & - \\
\hline $\begin{array}{c}\text { Immun } \\
\text { oblasts }\end{array}$ & $\begin{array}{l}\mathrm{B} \\
\mathrm{C}\end{array}$ & - & - & - & - & - & $\begin{array}{l}0 . \\
89\end{array}$ & - & - & $\begin{array}{l}0 . \\
89\end{array}$ & - \\
\hline $\begin{array}{l}\text { Immatu } \\
\text { re }\end{array}$ & $\begin{array}{l}\mathrm{I} \\
\mathrm{n}\end{array}$ & - & - & - & - & $\begin{array}{l}0 . \\
9\end{array}$ & - & - & - & - & - \\
\hline
\end{tabular}

\begin{tabular}{|c|c|c|c|c|c|c|c|c|c|c|c|}
\hline $\begin{array}{c}\text { plasma } \\
\text { B cells }\end{array}$ & & & & & & & & & & & \\
\hline $\begin{array}{c}\text { Mature } \\
\text { plasma }\end{array}$ & $\mathrm{I}$ & - & - & - & 0. & - & - & - & - & - & - \\
B cells & $\mathrm{n}$ & & & & 9 & & & & & & \\
\cline { 2 - 12 } & $\mathrm{C}$ & - & - & - & - & 0. & - & - & - & - & - \\
\hline $\begin{array}{c}\text { Reticula } \\
\text { r cells }\end{array}$ & $\mathrm{I}$ & - & - & - & - & - & - & - & 0. & - & - \\
\hline
\end{tabular}

Note. In, control (intact) group; BC, breast cancer group.

in the lymph nodes can also indicate maintaining activity of the local level of the immune response. In the paracortical zone, which plays a key role in the antitumor immune response, structural signs of maintaining the local immune response are also noted: the area of the paracortical zone remains at the level of the intact group, the number of macrophages is increased, and positively correlated the number of macrophages with chemokine MCP-1 is revealed. It is known that MCP-1, produced by mesenchymal stem cells, promotes the migration and metastasis of $\mathrm{BC}$ cells. In addition, mesenchymal stem cells also produce IL-6, which induces the migration and invasion of $\mathrm{BC}$ cells [2]. Apparently, the positive correlation of reticular cells with IL-6 may be due to its production by tumor cells and serve as one of the factors of growth and progression of the tumor. This can be indicated by the correlation of the number of reticular cells with M-CSF, which affects phagocytic activity, and may also be due to the growth of the primary tumor, and metastases in the lymph nodes. The revealed correlation of the number of mast cells, as factors contributing to homeostasis in the immune system, with IL-5, may also indicate a continuing activity of the local immune response aimed at antitumor protection. The positive correlation of the number of small lymphocytes and the number of mature plasma $\mathrm{B}$ cells with $\mathrm{GRO} / \mathrm{KC}$ chemokine, noted in the medullary sinuses, may be associated with the migration of small lymphocytes and mature plasma B cells from the lymph node. Increased production of IFN $\gamma$ is positively correlated with the number of immunoblasts in the medullary sinuses. In addition, the number of immunoblasts in the medullary sinuses in the group of animals with $\mathrm{BC}$ also significantly correlates with the chemokine MIP-3 $\alpha$.

\section{Conclusion}

Thus, with chemically induced $\mathrm{BC}$ a study of the correlation of cytokines of the lymph of the thoracic duct with morphological changes in the mesenteric lymph nodes revealed a number of dependencies that may be due to a local immune response in the lymph nodes directed on antitumoral protection.

\section{REFERENCES}

[1] M. I. Harrel, B. M. Iritani, A. Ruddell, "Tumor-induced sentinel lymph node lymphangiogenesis and increased lymph flow precede melanoma metastasis", Am. J. Pathol., vol 170(2), pp. 774-86, February 2007. DOI: 10.2353/ajpath.2007.060761

[2] A. P. Molloy, F. T. Martin, R. M. Dwyer, T. P. Griffin, M. Murphy, F. P. Barry, T. O'Brien., M. J. Kerin "Mesenchymal stem cell secretion of chemokines during differentiation into osteoblasts, and their potential role in mediating interactions with breast cancer cells", Int J Cancer, vol 124(2), pp. 326-32, January 2009. DOI: 10.1002/ijc.23939 